'has the best claim to fulfil a new role providing a real focus for plankton papers' Nature

An invitation to contribute and subscribe to

\title{
Journal of Plankton Research
}

Now six issues per year - change of frequency effective from Volume 5, 1983

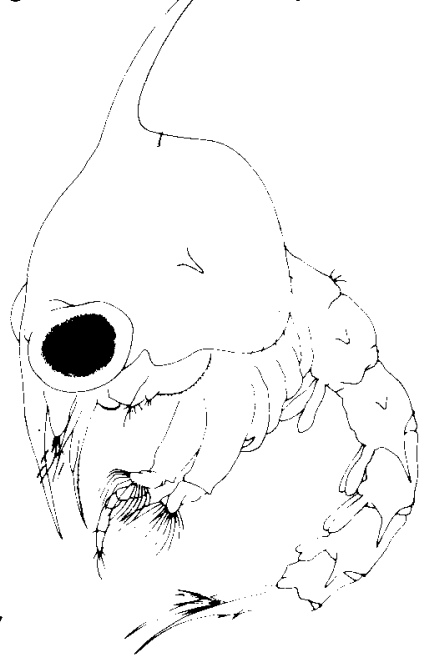

Journal of Plankton Research publishes papers dealing with both zoo and phytoplankton in marine, freshwater and brackish environments. The three main topics covered are the

- ecology of plankton, including larval and juvenile stages

- physiology of planktonic organisms including experimental results

- distribution, life histories and taxonomy of planktonic organisms

The editors welcome the submission of original research papers of all kinds from all over the world. The journal covers all planktonic environments, including organisms from the sea, lakes, ponds and rivers, as well as laboratory studies. The distribution of plankton is dealt with on an oceanic scale in the tradition of the old scientific expeditions and also on more restricted scales to ensure coverage of all essential processes.

A free sample copy, containing full 'notes for contributors', is available on request.

Executive Editor D.H. Cushing, Fisheries Laboratory, Lowestoft, Suffolk NR33 OHT, England Deputy Editor T. Wyatt, Fisheries Laboratory, Lowestoft, Suffolk NR33 OHT, England Editorial Board

B. Battaglia, Padova/G. Berge, Bergen/T. Björnberg, Sao Paulo/P. Bougis,

Villefranche-sur-Mer/E.D.S. Corner, Plymouth, UK/J.M. Colebrook, Plymouth, UK/N. Della Croce, Genova/R. Dugdale, West Boothbay Harbour/N. Duncan, London/R.S. Glover, Plymouth, UK/V. Hansen, Copenhagen/G. Hempel, Kiel/D. Harding, Lowestoft/O. KoblentzMishke, Moscow/R. Lebrasseur, Nanaimo/J. Lenz, Kiel/A. Longhurst, Dartmouth, Nova Scotia/R. Margalef, Barcelona/J.B.L. Matthews, Blomsterdalen/C. McAllister,

Nanaimo/J. McGowan, La Jolla/M.M. Mullin, La Jolla/W. Nellen, Kiel/M. Omori, Tokyo/ G.-A. Paffenhöfer, Savannah/T.R. Parsons, Vancouver/T. Petipa, Sevastopol/T. Platt, Dartmouth, Nova Scotia/S.Z. Qasim, Goa/M.R. Reeve, Miami/A. Sournia, Paris/M. Takahashi, Tsukuba/D.J. Tranter, Sydney/M. Vinogradov, Moscow/T. Vücetic, Split/J. Walsh, Upton, New York/C.S. Yentsch, West Boothbay Harbour

Subscription rates for Volume 5 ( 6 issues in 1983): libraries, f65.00/US\$150.00; individuals whose library subscribes $f 32.00 / \mathrm{US} \$ 75.00$

IRL Press, PO Box 1, Eynsham, Oxford OX8 1JJ, UK

IRL Press, Suite 907, 1911 Jefferson Davis Highway, Arlington VA 22202, USA

\section{IRL PRESS}




\section{The Biology}

of

\section{Marine Plants}

\section{M.J. Dring}

\section{Contemporary Biology Series}

This book provides an introduction to the modern analytical and experimental approach to marine plants and their environment. Although the book is biased towards marine algae (as approximately $90 \%$ of marine plants are algae), phytoplankton and algae are discussed together as far as possible in order to obtain an integrated picture. Examples are taken from oceans and coasts world-wide.

$£ 7.50$ paper 208 pages illustrated

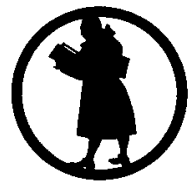

\section{Edward Arnold}

41 Bedford Square London WC1B 3DQ 


\section{THE MARINE BIOLOGICAL ASSOCIATION OF THE UNITED KINGDOM}

THE Association was founded in 1884 to promote accurate researches leading to the advancement of zoological and botanical science and to an increase in our knowledge of the food, life, conditions and habits of British fishes. The work of the Association is controlled by a Council elected annually by its subscribing members.

Professor T. H. Huxley took the chair at the initial meeting held in the rooms of the Royal Society and was elected the first President. Among those present were Sir John Lubbock (afterwards Lord Avebury), Sir Joseph Hooker, Professor H. N. Moseley, Mr G. J. Romanes, and Sir E. Ray Lankester who, after Professor Huxley, was for many years president of the Association. It was decided to build a laboratory at Plymouth, where a rich and varied fauna is found.

The Plymouth Laboratory was opened in June 1888, and, since that date, considerable additions have been made to the buildings, including a library, lecture-hall, and extensive laboratory accommodation with up-to-date equipment. Additional sea-water reservoirs have also been built, and an aquarium, modernized in 1959, opened to the public.

Since its foundation the Association has been supported by subscriptions and donations from private members, universities, learned societies, the Fishmongers' Company and other public bodies. For some time past, however, the main financial support for the work of the Plymouth Laboratory has come from Government funds, and since 1965 the Laboratory has been grant-aided through the Natural Environment Research Council.

The Marine Biological Association, under the direction of its Council, undertakes research in all branches of marine science and the main results are published in this journal. Accounts of the laboratory and aquarium are to be found in Vol. 27 (p. 761), Vol. 39 (p. 391) and Vol. 43 (p. 281), and summaries of the activities and research of the Association are given annually in the Report of the Council in the November issue of the Journal.

The laboratory is open throughout the year and its work is carried out by a fully qualified research staff under the supervision of the Director. The names of the members of the staff will be found on the inner page of the front cover. Accommodation is available for British and foreign scientific workers who wish to carry out independent research in all branches of marine science. Arrangements are made for courses for advanced students, and marine animals and plants are supplied to educational institutions.

Work at sea is undertaken by three research vessels and by a motor boat, and these also collect the specimens required in the laboratory.

\section{TERMS OF MEMBERSHIP}

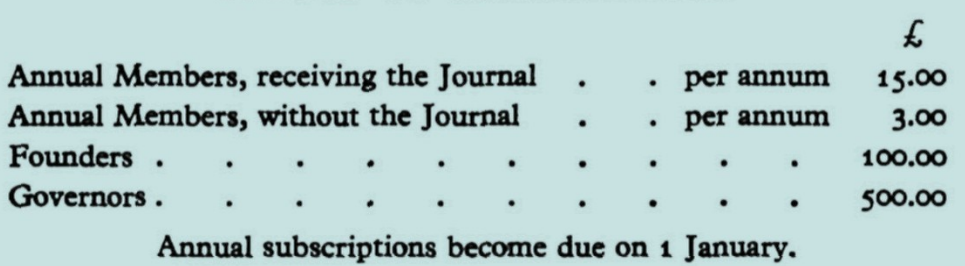

Members of the Assocation have the following rights and privileges: they elect annually the Officers and Council; they are entitled to receive the Journal of the Association at a reduced rate; they are admitted to view the laboratory at Plymouth; they have the first claim to rent a place in the laboratory for research, with use of tanks, boats, etc.; they have the privilege of occupying a table for one week in each year free of charge; and they have access to the books in the library at Plymouth during working hours.

The Commissioners of Inland Revenue have approved the Association for the purposes of Section 16, Finance Act, 1958, and that the whole of the annual subscription paid by a member who qualifies for relief under the section will be allowable as a deduction from his emoluments assessable to income tax under Schedule E.

All correspondence should be addressed to the Director, The Laboratory, Citadel Hill, Plymouth, PL1 2PB. 


\section{CONTENTS}

Quicke, D. L. J. and BrACB, R. C. Phenotypic and genotypic spacing within an aggregation of the anemone, Actinia equina

SHRADER, M. The reproductive biology and ecology of Gammarus duebeni (Crustacea: Amphipoda) in southern England .

GUBBAY, S. Compressive and adhesive strengths of a variety of British barnacles . .

Young, J. Z. Control of movements of the stomach and spiral intestine of Raja and Scyliorhinus

Gattzin, R. R., SARGint, J. R. and Gambla, J. C. Diet-induced changes in fatty acid composition of herring larvae reared in enclosed ecosystems

AUSTIN, B. Bacterial microflora associated with a coastal, marine fish-rearing unit . .

KIRKRganRD, J. B. Bathyal benthic polychaetes from the N.E. Atlantic Ocean, S.W. of the British Isles

TYLRR, P. A. and GAGB, J. D. The reproductive biology of Ypsilothuria talismani (Holothuroidea: Dendrochirota) from the N.E. Atlantic ..... .

Crrtchuby, A. T. Sargassum muticum: a taxonomic history including world-wide and western

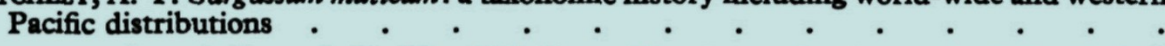

MaUchirne, J. and GAGE, J.D. The Nebaliacea (Crustacea: Leptostraca) of the Rockall Trough . . . . . . . . . . . . . .

DAVENPORT, J. Oxygen and the developing eggs and larvae of the lumpfish, Cyclopterus lumpus

YounG, G. A. The effect of sediment type upon the position and depth at which byssal attachment occurs in Mytilus edulis . . . . . . . . . . .

Young, G. A. Response to, and selection between, firm substrata by Mytilus edulis . .

Mason, A. Z. and Simkiss, K. Interactions between metals and their distribution in tissues of Littorina littorea (L.) collected from clean and polluted sites . . . . .

Manahan, D. T. and CRISP, D. J. Autoradiographic studies on the uptake of dissolved amino acids from sea water by bivalve larvae

DYkR, M. F., FrY, W. G., FrY, P. D. and Cranmer, G. J. Benthic regions within the North

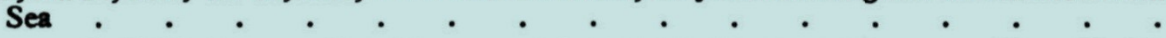

Strbbing, A. R. D., Clrary, J. J., Brinsley, M., Goodchild, C. and Santiago-Fandiño, V. Responses of a hydroid to surface water samples from the River Tamar and Plymouth Sound in relation to metal concentrations

DavenPort, J., Lenning, S. and KJørsvix, E. Ammonia output by eggs and larvae of the lumpsucker, Cyclopterus lumpus, the cod, Gadus morhua and the plaice, Pleuronectes platessa

Thomas, M. L. H. and PAGE, F. H. Grazing by the gastropod, Lacuna vincta, in the lower intertidal area at Musquash Head, New Brunswick, Canada . . . . $\quad . \quad 725$

Book Noticks

C. Copyright by the Marine Biological Association of the U.K. 1983

The subscription price of volume 63, 1983 of the Journal to non-members of the Association is $£ 86.00$ net a volume of four parts, post free, or US $\$ 225.00$ in U.S.A. and Canada, payable in advance. Single parts cost $£ 25.00$ (US $\$ 66.00$ in U.S.A. and Canada) plus postage. Subscriptions may be sent to any bookseller or to Cambridge University Press, The Edinburgh Building, Shaftesbury Road, Cambridge CB2 2RU, or in the U.S.A. and Canada, to Cambridge University Press, 32 East 57th Street, New York, 10022 . All orders must be accompanied by payment.

\section{CAMBRIDGE UNIVERSITY PRESS}

\section{THE PITT BUILDING, TRUMPINGTON STREET, CAMBRIDGE CB2 1 RP}

32 EAST S7TH STREET, NEW YORK, N.Y. 10022

Printed in Great Britain at the University Press, Cambridge 